Article

\title{
Dual Institutional Pressures, Sustainable Supply Chain Practice and Performance Outcome
}

\author{
Yali Lu ${ }^{1,2}$, Chenyang Zhao ${ }^{2}$, Leimeng $\mathrm{Xu}^{2}$ and Lei Shen ${ }^{1, *}$ \\ 1 Institute of Geographic Sciences and Natural Resources Research, CAS, Beijing 100101, China; \\ luyali@ncwu.edu.cn \\ 2 School of Management and Economics, North China University of Water Resources and Electric Power, \\ Zhengzhou 450046, China; 17125523@bjtu.edu.cn (C.Z.); xuleimengie@163.com (L.X.) \\ * Correspondence: shenl@igsnrr.ac.cn; Tel.: +86-187-399-36530
}

Received: 23 July 2018; Accepted: 3 September 2018; Published: 12 September 2018

check for updates

\begin{abstract}
With the deterioration of ecological environment, sustainable supply chain management has become an important means of enterprise performance evaluation. During the implementation of a sustainable supply chain management (SSCM), Chinese enterprises are faced with domestic and overseas institutional pressures, such as laws, regulations, and agenda, etc. Then, whether the dual institutional pressure has a promoting role for Chinese manufacturing enterprises in implementing the SSCM and whether the sustainable supply chain practices (SSCP) can promote the output of enterprise performance, have become a topic worthy of study. Hypothesis on the relationship between the institutional pressure of sustainable supply chain and economic, social, and environmental performances is innovatively raised in this paper and a theoretical model is built. Besides, a fitting test is conducted to a full model by using a structural equation model. An optimal model is eventually obtained after repeated modifications to the initial model by means of goodness of fit and causal path coefficient, thereby it is verified in this paper that the institutional pressure has a significantly positive impact on the SSCP; a conclusion is drawn that the impact of the SSCP on the economic, environmental, and social performances shows different characteristics, which has an important theoretical guiding role in promoting the SSCP.
\end{abstract}

Keywords: institutional pressure; sustainable supply chain; performance outcome; structural equation model

\section{Introduction}

The idea of introducing the sustainable supply chain management (SSCM) ideas into enterprise performance evaluation has aroused hot discussions among domestic and overseas scholars $[1,2]$. China is a large manufacturing country in the world; so, Chinese enterprises are faced with domestic and overseas institutional pressures, such as laws, regulations, and agenda, etc. during the implementation of SSCM [3]. On the one hand, China has promulgated Environmental Protection Law, Air Pollution Control Law, Solid Waste Pollution Prevention and Treatment Law, Our Common Future, China's Agenda 21, and so on successively to restrict the behavior of enterprises, and, on the other hand, since China's accession to the WTO, Chinese enterprises are facing a severe test of the international system. For example, New Energy Act of the United States, Renewable Energy Act of Germany, and Energy Policy Act of France have stricter requirements and regulations on suppliers.

Whether dual institutional pressures can promote the implementation of SSCM for Chinese manufacturing enterprises and whether the sustainable supply chain practices (SSCP) can promote the output of enterprise performance have become a topic worthy of study. This article is to answer the above two problems. 
The literature on Sustainable supply chain is rich and has been researched, which is mainly embodied in the definition, implementation of the driving force and pressure, model mechanism, and performance evaluation of SSCM. In terms of the performance dimensions of sustainable supply chain, Enterprises should meet the three bottom line of balanced development of economy, society, and environment. (The Triple Bottom Line, TBL) [4], but the economic benefit dimension and the environmental dimension are considered in most of the, and the social benefit dimension is considered only in some of the literatures [5,6], this could be due to the fact that social issues are often difficult to measure [7]. The literature reviews on SSCM hat cover at least two sustainability dimensions are considered [8]. In terms of research on the relationship between sustainable supply chain institutional pressure and performance outcome, most scholars believe that institutional pressure can promote SSCP [9-12]. Institutional pressure can promote the SSCP of manufacturing enterprises in the United Kingdom and SSCP shows a significantly positive effect on the performance outcome of enterprises [13]. From the above literature research, we can see that the governance pressure, particularly the institutional pressure, can promote SSCP, and SSCP has a positive effect on the performance outcome, this provides great inspiration for the research of this paper. However, China's national conditions determine that Chinese enterprises have their own uniqueness.

The topic of whether institutional pressure can promote the implementation of SSCM for Chinese enterprises and what is the relationship between SSCP and triple performance output are the research focus of this paper.

The innovation and contribution of the research have the following three aspects.

First, most previous studies in China only consider the economic benefit and environmental benefits, but under the instructions of TBL [14], the research proposes that the performance outcomes include the environment, economic, and social performances. Therefore, in this paper, the performance not only considers the economic benefit, environmental benefit, but it also considers the social benefit, which is the improvement and supplement to the previous research.

Secondly, By taking institutional pressure into account in the study on the relationship between SSCP and performance output, and combing domestic and exporting country's environmental regulations and institutional pressure faced by Chinese enterprises, first-hand data from enterprises are collected through questionnaire survey, and, in this paper, in-depth study about the relationship between institutional pressure and SSCP and the relationship between SSCP and performance output is carried out, which is very important for guiding the government to encourage enterprises and help enterprises to improve enterprise performance and management style in the right way.

Finally, on the basis of previous studies on sustainable supply chain performance, the innovative research is conducted on the relationship between SSCP and social performance in this paper, which provides a powerful reference for enterprises to focus on social performance.

The remainder of the paper is organized, as follows: in Section 2, we review the related literature and carry out the hypotheses development. In Section 3, the problem of scale development and data collection are described, and the reliability and validity analysis are conducted. In Section 4, the relationship between institutional pressure and performance outcome of sustainable supply chain results by Structural Equation Model are discussed, then reliability and validity analysis, fitting analysis, model modification, and hypothesis testing are conducted, ultimately coming to a conclusion. Finally, we present conclusions in Section 5.

\section{Literature Review and Hypotheses Development}

\subsection{Related Literature Review}

\subsubsection{Research on the Definition of SSCM}

Sustainability and supply chain management are two concepts that have created many debates independently over the last decade [15]. In recent years, as a new overlapping research field, sustainable supply chain has been favored by scholars at home and abroad. Most studies show that SSCM is 
the integration of sustainable development and supply chain. Sustainable development restricts the enterprise's strategies and behaviors, and it is the integration that is carried out by people for the economic, environmental, and social issues that are related to development. The differences of key characteristics between green supply chain management (GSCM) and sustainable supply chain management (SSCM) for business sustainability (i.e., economic, environmental, social, stakeholder, volunteer, resilience, and long-term focuses) and SCM (i.e., flow, coordination, stakeholder, relationship, value, efficiency, and performance focuses) were proposed [14]. Customers constantly increase their demands for sustainable products, examine food industry according to SSCM and DC standards from the perspective of economy, ecology, and social environment, and they provide the strategies that are used in the commercial market [16]. Taking auto industry as an example, social responsibility in the risk assessment system of SSCM might be considered and SSCM risks of Honda, Volkswagen, and General Motors from the aspects, such as internal, external, and partner, etc. can be compared [17]. The social responsibility in the research content system is considered and an optimal model of carbon emission trading mechanism is built by utilizing the theory of Triple Bottom Line (TBL) [18]. The long-term sustainable development potential of the developed automated guided vehicles (AGV) on economy, society, and environment is considered, thereby the planning and design for AGV system need to be carried out [19]. Coordinated management and operation innovation by utilizing SSCM idea from the perspectives of economy, society, and environment are defined, and the key links that manufacturing enterprises shall pay attention to during the sustainable management are pointed out [20]. In general, traditional supply chain management normally pays attention to financial performance only, while SSCM attaches importance to economic, environmental, and social performances, providing theoretical guidance for the research.

\subsubsection{SSCP}

SSCP refers to the management activities of the sustainable supply chain implemented by enterprise to achieve the more sustainable of the sustainable supply chain on the three dimensions of economic, social, and environmental benefits [21,22]. It generally includes a series of operation activities, such as sustainable production within enterprises, packaging, and transportation [23]. At present, most of the large-scale multinational enterprises that implement SSCM in China have put forward requirements on suppliers' environmental protection. National, regional, and environmental regulations in exporting countries are confirmed. For example, they demand the supply of products with ecological labels and the prohibition of using hazardous substances.

SSCP refer to management activities of sustainable supply chain implemented by enterprises to make its supply chain more sustainable in terms of all three dimensions of sustainability [21-23], which generally include a series of operation activities, such as sustainable production, package, and transportation, etc. in the enterprises. Most of the large transnational enterprises implementing SSCM in China now have required that the environmental protection made by suppliers shall conform to the environmental legislations of the country, region, and exporter. For example, they require that the supplied products shall have ecological labels and that the use of hazardous substances shall be prohibited.

In this paper, a comparative analysis for the SSCP of some well-known manufacturing enterprises at home and abroad is made, as shown in Table 1. Through comparison, we find that the manufacturing industry will generally focus on sustainable supply chain design, procurement and transportation, investment recovery, and other practical contents. Four under-lying dimensions of SSCP incorporating sustainable product design, process design, and sustainability collaboration with suppliers, as well as customers are identified [22,23]. Similarly, four areas (sustainable production, sustainable design, sustainable distribution, and investment recovery) in SSCP are focused on [24]. Combining the contents of enterprise practice, such as design, procurement, transportation, and investment recovery, etc. of sustainable supply chain, the classification method of sustainable supply chain practice given by Esfahbodi et al. is adopted in this paper [24]. 
Table 1. Sustainable supply chain practices (SSCP)contents of domestic and foreign enterprises.

\begin{tabular}{|c|c|}
\hline Company & Classification of SSCP; (Practice Contents) \\
\hline IBM & $\begin{array}{l}\text { (1) Certified by ISO 140001; (design) } \\
\text { (2) More concerned about the content of harmful substances in products; (procurement) } \\
\text { (3) Batteries and plastic products comply with WEEE regulations; (procurement) }\end{array}$ \\
\hline $\mathrm{HP}$ & $\begin{array}{l}\text { (1) Certified by ISO 14001; (procurement) } \\
\text { (2) Harmful substances are limited in products; (procurement) } \\
\text { (3) The corporate social responsibility, environmental rules and other requirements are } \\
\text { clarified to suppliers; (procurement) } \\
\text { (4) The environmental report should be based on the standard of European recycling } \\
\text { platform; (design) }\end{array}$ \\
\hline SONY & $\begin{array}{l}\text { (1) Certified by ISO 14001; (design) } \\
\text { (2) Formulating medium-term and long-term plan; (design and investment; (Recovery) } \\
\text { (3) Restriction of harmful substances in products based on sustainable supply chain } \\
\text { procurement standards; (procurement) }\end{array}$ \\
\hline SAMSUNG & $\begin{array}{l}\text { (1) Certified by ISO 14001; (design) } \\
\text { (2) The use of hazardous substances are controlled according to "OQA-2049"; (design) } \\
\text { (3) Providing environmental reports in conjunction with "eco partners"; (distribution) }\end{array}$ \\
\hline $\begin{array}{c}\text { Shanghai } \\
\text { General Motors }\end{array}$ & $\begin{array}{l}\text { (1) Requires suppliers to reduce energy consumption by } 5-10 \% \text {; (procurement) } \\
\text { (2) Requires suppliers to reduce water consumption and waste by } 5-10 \% \text {; (procurement) } \\
\text { (3) Requires greenhouse gas and non-greenhouse gas pollution to be reduced by } 5-10 \% \text {; } \\
\text { (procurement) }\end{array}$ \\
\hline Haier & $\begin{array}{l}\text { (1) Product design should take into account the repeated utilization and recovery of raw } \\
\text { materials; (design and investment recovery) } \\
\text { (2) Reducing the use of toxic and harmful materials; (procurement) } \\
\text { (3) Construction of an ecological industrial park for home appliance recycling; } \\
\text { (distribution) } \\
\text { (4) An assessment tool for researching and Manufacturing the carbon footprint of white } \\
\text { electric products in accordance with international standards; (distribution) }\end{array}$ \\
\hline Huawei & $\begin{array}{l}\text { (1) Develop product projects with customers; (design and investment recovery) } \\
\text { (2) Improve the sustainability of supplier certification and performance evaluation; } \\
\text { (procurement) } \\
\text { (3) Regular review of supplier environmental performance; (procurement) } \\
\text { (4) Optimizing internal management process; (design and investment recovery) } \\
\text { (5) Formulating IPC1401 Practice Guide; (procurement) }\end{array}$ \\
\hline
\end{tabular}

Source: According to the corporate social responsibility report (2016).

\subsubsection{Research on the Performance of Sustainable Supply Chain}

With respect to the evaluation on the performance of sustainable supply chain, the scholars conducted a research with different methods from various perspectives. The representative researches are shown, as follows. An evaluation system is established based on development and survivability as well as adaptability to social and natural environments, and rank performances with the improved TOPSIS method [25]. By studying supply chains of four large companies in Brazil through cases, the influences of practices of green supply chain management (GSCM), including green energy on the indexes of environment and operation performances is investigated [26]. A performance valuation system for sustainable supply chains based on operational, environmental, social, and economic performances is built and is made fitting analysis with the structural equation model. Furthermore, the performance outcome is evaluated through empirical analysis to explain that this method is scientific and effective [27]. A performance evaluation system for SSCM is established based on social, economic, and environmental performances from the perspective of balanced scorecard. Moreover, the performance of the sustainable supply chain is innovatively assessed by utilizing the integrated BSC-DEA method [28]. A performance factor evaluation system is set up of the sustainable supply chain based on profitability, economic growth, market share, employee and customer satisfaction, 
and flexibility. The influence of dynamic capability on the enterprise performance of the sustainable supply chain is explored through grey analysis [29]. According to the references above, a complete set of performance index system of the sustainable supply chain has not been formed at present. Most researches ignore such problems as interaction among index factors, impacts of current various institutional pressures on SSCP, and relational analysis between SSCP and performance outcome. Therefore, based on the existing domestic and foreign researches, the effect of the institutional pressure in SSCP is comprehensively taken into account herein, and the influence of SSCP on performance outcome is researched.

\subsubsection{The Research on the Institutional Pressure of Sustainable Supply Chain}

Scholars have not yet reached a unified understanding of the concept of institutional pressure [30,31], and the relevant research that can be found demonstrates that managers have to consider and give some corresponding factors in the process of management based on the existing social systems that are not changed $[32,33]$. The managers tend to view institutional pressure as an external driving force for optimizing management decisions under existing institutional constraints $[30,34,35]$. However, the most important research tends to be the government's constraint on social organizations as the governance stress research. In the institutional pressure, the coercive pressure refers to the integration due to the influence of authority, which is an important factor of promoting manufacturing enterprises to take environmental measures [9]. Companies under supervision shall particularly concern the corresponding environmental adjustment, especially under the supply chain background. Resource dependence, transaction cost economics, and institutional theories have been used to learn how the enterprises taken environment measures through supply chain [10]. Companies with a complex supply chain are under greater and greater pressures from each stakeholder, especially government, so they need to undertake the responsibilities of social and environmental problems beyond their organizational boundaries [11]. According to the "institution-behavior-performance", institutional pressure has a significantly positive influence on the relationship management of supply chain and the design of sustainable supply chain [12]. According to the references above, governance pressure, particularly institutional pressure, can promote SSCP and such practices positively influence the performance outcome, this will greatly enlightening the research.

\subsection{Theoretical Analysis and Hypotheses}

2.2.1. Hypothesis on the Relationship between Institutional Pressure and Performance Outcome of Sustainable Supply Chain

In the current researches, many scholars argue that institutional pressure can promote SSCP, and such practices can in turn improve performance outcome $[9,11,12,21]$. Therefore, the institutional pressures, such as environmental laws and regulations etc. and SSCP, along with and performance outcome, are linked herein. Moreover, the main hypothesis is divided into six sub-hypotheses, as follows.

\section{(1) Hypothesis on the relationship between institutional pressure and SSCP}

The majority of researches show that institutional pressure can promote SSCP. In the governance of pressure, institutional pressure indicates the integration due to the influence of authority, which is an important factor of promoting manufacturing industry to take environmental measures [9]. Companies with a complex supply chain are under greater and greater pressures from each stakeholder, especially government, so they need to undertake the responsibilities of social and environmental problems beyond their organizational boundaries [11]. It is indicated that institutional pressure is prominent in the SSCP and it can promote the implementation of SSCM [12]. Therefore, the following hypotheses are raised herein.

Hypothesis 1 (H1). Institutional pressure has a significantly positive influence on SSCP. 
Hypothesis 1a (H1a). Institutional pressure has a significantly positive influence on sustainable supply chain procurement.

Hypothesis $\mathbf{1 b} \mathbf{( H 1 b ) . ~ I n s t i t u t i o n a l ~ p r e s s u r e ~ h a s ~ a ~ s i g n i f i c a n t l y ~ p o s i t i v e ~ i n f l u e n c e ~ o n ~ s u s t a i n a b l e ~ s u p p l y ~}$ chain distribution.

Hypothesis 1c (H1c). Institutional pressure has a significantly positive influence on sustainable supply chain design.

Hypothesis 1d (H1d). Institutional pressure has a significantly positive influence on investment recovery.

\section{(2) Hypothesis of the relationship between SSCP and environmental performance}

In essence, the four major aspects of SSCP (i.e., sustainable supply chain procurement, distribution, design, and investment recovery) are environment-friendly measures. The purpose of such measures is to reduce the influence of the products on environment as much as possible. Therefore, in theory, SSCP can decrease the consumption of raw materials by enterprises, thereby improving environmental performance. Most literatures also indicate that SSCP can improve environmental performance. It is considered that the connection of organizations and the cooperation with suppliers are conducive to utilizing innovative environmental technologies and improving environmental performance [36]. SSCM is positively correlated with environmental performance [12,37]. Thereby, the following hypotheses are put forward herein:

Hypothesis 2 (H2). SSCP have a prominently positive impact on environmental performance.

Hypothesis 2a (H2a). Sustainable supply chain procurement has a prominently positive impact on environmental performance.

Hypothesis $\mathbf{2 b} \mathbf{( H 2 b ) . ~ S u s t a i n a b l e ~ s u p p l y ~ c h a i n ~ d e s i g n ~ h a s ~ a ~ p r o m i n e n t l y ~ p o s i t i v e ~ i m p a c t ~ o n ~}$ environmental performance.

Hypothesis 2c (H2c). Sustainable supply chain distribution has a prominently positive impact on environmental performance.

Hypothesis $\mathbf{2 d} \mathbf{( H 2 d ) . ~ I n v e s t m e n t ~ r e c o v e r y ~ h a s ~ a ~ p r o m i n e n t l y ~ p o s i t i v e ~ i m p a c t ~ o n ~ e n v i r o n m e n t a l ~ p e r f o r m a n c e . ~}$

\section{(3) The relationship between SSCP and economic performance}

Essentially speaking, SSCP mainly concentrate on eliminating the wastes in material procurement, product design, delivery, and disposal. Eliminating wastes can reduce costs and improve economic performance. It is put forward that formal and informal contact mechanism of enterprises generally can foster trust, reduce risk, and enhance cooperation and promises, thereby improving their profitability [38]. Environmental management schemes, like SSCP, are positively correlated with economic performance of organizations. The practices of environmental management can enhance enterprise reputation and customer satisfaction and in turn improve economic performance [39]. Thus, the hypotheses are put forward, as follows:

Hypothesis 3 (H3). SSCP have a significantly positive impact on economic performance.

Hypothesis 3a (H3a). Sustainable supply chain procurement has a significantly positive impact on economic performance. 
Hypothesis $\mathbf{3 b} \mathbf{b} \mathbf{H} 3 \mathbf{b})$. Sustainable supply chain design has a significantly positive impact on economic performance.

Hypothesis 3c (H3c). Sustainable supply chain distribution has a significantly positive impact on economic performance.

Hypothesis 3d (H3d). Investment recovery has a significantly positive impact on economic performance.

\section{(4) The relationship between SSCP and social performance}

SSCP in essence emphasize on improving environment and undertaking social responsibility. It is necessary to integrate the sustainability of social responsibility into management for business operation. When the cooperation between enterprises and suppliers joins the concept of sustainability, the enterprise will establish its social reputation and image. Therefore, the supervision and evaluation conducted by enterprises for suppliers and the sustainable cooperation between enterprises and suitable suppliers will mean the improvement of social sustainable value [40]. It is believed that enterprises that are actively taking environmental actions and fulfilling social responsibilities can improve employee and customer satisfactions and corporate reputation, consequently improving economic indexes and making up cost input [27]. It is found that SSCM, including environmental, technological, culture, and risk management positively affects the health industry in Malaysia [41]. Hence, the following hypotheses are raised herein.

Hypothesis 4 (H4). SSCP have a significantly positive influence on social performance.

Hypothesis 4a (H4a). Sustainable supply chain procurement has a significantly positive influence on social performance.

Hypothesis $4 \mathbf{b} \mathbf{( H 4 b ) . ~ S u s t a i n a b l e ~ s u p p l y ~ c h a i n ~ d e s i g n ~ h a s ~ a ~ s i g n i f i c a n t l y ~ p o s i t i v e ~ i n f l u e n c e ~ o n ~}$ social performance.

Hypothesis 4c (H4c). Sustainable supply chain distribution has a significantly positive influence on social performance.

Hypothesis 4d (H4d). Investment recovery has a significantly positive influence on social performance.

\section{(5) The relationship between environmental performance and economic performance}

In some researches, the scholars maintain that environmental performance can enhance economic performance. For example, it is pointed out that costs saved by environmental performance naturally improve economic performance and reduce the relevant support costs [42]. Environmental performance shows a positive impact on economic performance [14]. Therefore, the following hypotheses are raised:

Hypothesis 5 (H5). Environmental performances has a significantly positive impact on economic performance.

\section{(6) The relationship between social performance and economic performance}

The relevant researches regarding the influence of social performance on economic performance under institutional pressure and the implementation of SSCP have not been found in the currently retrieved references. However, we know that Economic performance, environmental performance, and social performance are not isolated; they are related to each other. Social responsibility is a global indicator that is used to assess a company's social performance [43,44]. If an enterprise actively assumes environmental and social responsibilities, this will not only enhance employee satisfaction, customer 
satisfaction, and the reputation level of enterprise, but it also will eventually lead to more customer groups and increase in sales, and have a positive impact on enterprise economic performance [27]. That is to say, a social responsibility needs to meet the internal and external customers' expectations and satisfaction [45]. So, the relationship between the corporate performance and the social performance centered on customer rights and benefits is explored, and it illustrates that the social performance will promote the ultimate improvement of economic performance [46]. Therefore, the following hypotheses are put forward:

Hypothesis 6 (H6). Social performances has a significantly positive influence on economic performance.

2.2.2. Theoretical Model of the Relationship between Institutional Pressure and Performance Outcome of Sustainable Supply Chain

Based on the analysis above, the theoretical model herein is a path analysis model of eight latent variables, i.e., institutional pressure, sustainable supply chain procurement, sustainable supply chain design, sustainable supply chain distribution, investment recovery, economic performance, environmental performance, and social performance. Each hypothesis is significant and positive in the theoretical model. Furthermore, institutional pressure in the form of environmental legislation can drive SSCP, and such practices subsequently affect the economic, environmental, and social performances of sustainable supply chain. The specific theoretical model is as shown in Figure 1 and the definition of the model is as shown in Table 2.

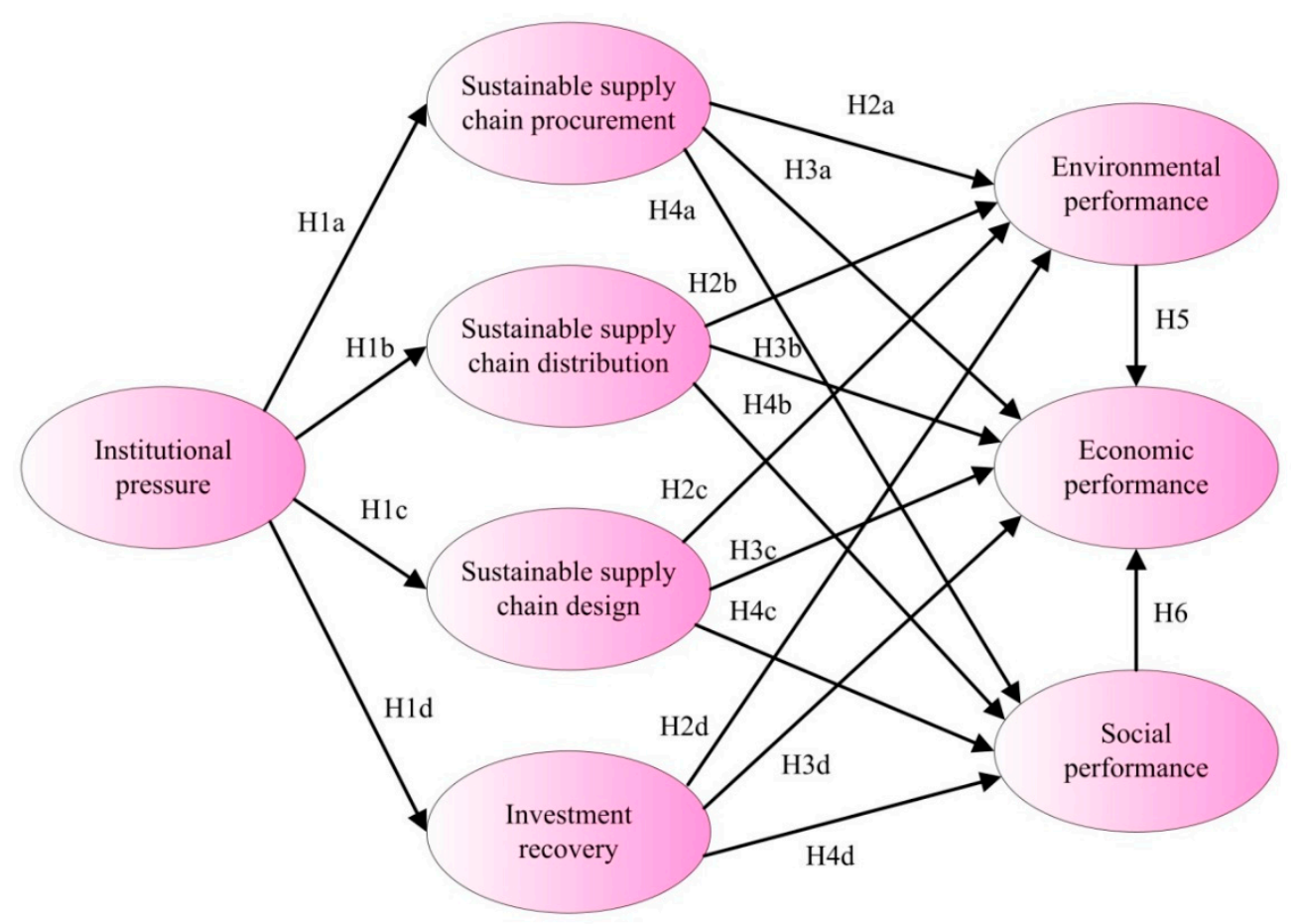

Figure 1. Theoretical Model of the Relationship between SSCP and Performance Outcome under Institutional Pressure. 
Table 2. Structural Definition of Concept Model of the Relationship between Governance Pressure and Performance Outcome of Sustainable Supply Chain.

\begin{tabular}{|c|c|c|}
\hline Structure & Definition & Sources \\
\hline $\begin{array}{l}\text { Institutional } \\
\text { pressure }\end{array}$ & $\begin{array}{l}\text { Laws and regulations to strengthen the company's } \\
\text { environmental adjustment; }\end{array}$ & {$[9,25,30,34]$} \\
\hline $\begin{array}{l}\text { Sustainable supply } \\
\text { chain procurement }\end{array}$ & $\begin{array}{l}\text { Sustainable supply chain procurement lays emphasis on } \\
\text { cooperation with suppliers, aiming to develop environmental } \\
\text { sustainable products; }\end{array}$ & [24] \\
\hline $\begin{array}{l}\text { Sustainable supply } \\
\text { chain distribution }\end{array}$ & $\begin{array}{l}\text { Sustainable supply chain distribution refers to the } \\
\text { transportation mode of any products or services from suppliers } \\
\text { to manufacturers and final customers, aiming to reduce negative } \\
\text { influences on environment; }\end{array}$ & [24] \\
\hline $\begin{array}{l}\text { Sustainable supply } \\
\text { chain design }\end{array}$ & $\begin{array}{l}\text { Sustainable supply chain design requires that the products } \\
\text { designed by manufacturers should be produced with as few } \\
\text { materials and little energy as possible for the convenience of } \\
\text { recovery and recycling. Besides, harmless substances shall be } \\
\text { used; }\end{array}$ & {$[24]$} \\
\hline $\begin{array}{l}\text { Investment } \\
\text { recovery }\end{array}$ & $\begin{array}{l}\text { Investment recovery is a process of recovering unused value } \\
\text { and selling lifelong assets through effective recycling or surplus. } \\
\text { Therefore, redundant inventory, wastes and equipment etc. } \\
\text { need selling; }\end{array}$ & [24] \\
\hline $\begin{array}{l}\text { Environmental } \\
\text { performance }\end{array}$ & $\begin{array}{l}\text { Environmental performance refers to the ability of } \\
\text { manufacturing enterprises to reduce the emissions of exhaust } \\
\text { gas, waste water and solid waste as well as risks and the } \\
\text { consumption of toxic substances; }\end{array}$ & {$[21,22]$} \\
\hline $\begin{array}{l}\text { Economic } \\
\text { performance }\end{array}$ & $\begin{array}{l}\text { Economic performance refers to the reduction of purchased } \\
\text { materials, energy consumption, waste discharge and disposal, } \\
\text { and fines of environmental accidents; }\end{array}$ & {$[21,22]$} \\
\hline Social performance & $\begin{array}{l}\text { Social performance refers to the ability of manufacturing } \\
\text { enterprises to improve the satisfactions of employees and } \\
\text { customers as well as the reputation of enterprises. }\end{array}$ & {$[21,22]$} \\
\hline
\end{tabular}

\section{Research on Scale Development and Data Collection}

\subsection{Scale Development and Questionnaire Design}

\subsubsection{Scale Development}

A scale is a quantitative tool for measuring subjective or abstract concepts. In this paper, the Likert scale is selected to measure the research, because the five answer forms of the scale enable the respondent to mark his/her position conveniently, it can avoid the bias when the respondent know the purpose of the study. So, all the measurements used a five-point Likert scale measurement in items of the relationship between institutional pressure and performance outcome of sustainable supply chain are given in Table $3[27,38,44]$. 
Table 3. Measurement Items of the Relationship between Institutional Pressure and Performance Outcome of Sustainable Supply Chain.

\begin{tabular}{|c|c|}
\hline Variables & Measurement Items \\
\hline Institutional pressure (CP) & $\begin{array}{l}\text { CP1 National environmental laws and regulations (such as waste } \\
\text { discharge and clean production etc.) } \\
\text { CP2 Regional environmental laws and regulations (such as waste } \\
\text { discharge and clean production etc.) } \\
\text { CP3 Environmental legislation of exporters } \\
\text { CP4 Potential conflicts of products and laws (such as cyclic economy, } \\
\text { EPR and EHS etc.) }\end{array}$ \\
\hline $\begin{array}{l}\text { Sustainable supply chain } \\
\text { procurement (SP) }\end{array}$ & $\begin{array}{l}\text { SP1 Ecological labels of products } \\
\text { SP2 Cooperation of environmental objectives with suppliers } \\
\text { SP3 Environmental audit of internal management of suppliers } \\
\text { SP4 ISO14001 certification of suppliers } \\
\text { SP5 Evaluation on environmental protection practices of second-tier } \\
\text { suppliers }\end{array}$ \\
\hline $\begin{array}{l}\text { Sustainable supply chain } \\
\text { distribution (SD) }\end{array}$ & $\begin{array}{l}\text { SD1 Use less energy during the distribution of products } \\
\text { SD2 Use renewable energy in the transportation mode of any products } \\
\text { SD3 Update freight logistics and transportation system (both software } \\
\text { and hardware, such as reducing aeronautical miles and the weight of } \\
\text { containers, improving refrigeration etc.) } \\
\text { SD4 Track and monitor the emission (carbon footprint) during the } \\
\text { distribution }\end{array}$ \\
\hline $\begin{array}{l}\text { Sustainable supply chain design } \\
\text { (SDESI) }\end{array}$ & $\begin{array}{l}\text { SDESI1 Decrease the consumption of materials and raw materials in the } \\
\text { design of products } \\
\text { SDESI2 Re-utilize the designed products and recycle the raw materials, } \\
\text { parts and semi-finished products } \\
\text { SDESI3 The designed products shall avoid or reduce the utilization of } \\
\text { hazardous substances in the manufacturing process }\end{array}$ \\
\hline Investment recovery (IR) & $\begin{array}{l}\text { IR1 Recycle or sell excessive inventory or materials } \\
\text { IR2 Sell waste materials or byproducts } \\
\text { IR3 Sell idle equipment assets }\end{array}$ \\
\hline Environmental performance (EVN) & $\begin{array}{l}\text { EVN1 Reduce the discharge of exhaust gas, waste water and solid waste } \\
\text { EVN2 Decrease the consumption of harmful/toxic substances } \\
\text { EVN3 Reduce the frequency of environmental accidents } \\
\text { EVN4 Improve enterprise environment }\end{array}$ \\
\hline Economic performance (ECP) & $\begin{array}{l}\text { ECP1 Decrease the costs of purchased materials } \\
\text { ECP2 Decrease the costs of energy consumption } \\
\text { ECP3 Reduce waste handling charges } \\
\text { ECP4 Reduce pollutant charges } \\
\text { ECP5 Reduce the fines of environmental accidents }\end{array}$ \\
\hline Social performance (SOC) & $\begin{array}{l}\text { SOC1 Improve employee satisfaction } \\
\text { SCO2 Improve customer satisfaction } \\
\text { SOC3 Improve corporate reputation }\end{array}$ \\
\hline
\end{tabular}

\subsubsection{Questionnaire Design}

On the basis of the scale development, the questionnaire is designed according to China's actual conditions, the characteristics of each industry and the domestic and foreign references.

There are five typical enterprises in the manufacturing industry: (1) Thermal power plants and chemical/petrochemical enterprises. These two types of enterprises are enterprises that will cause serious environmental pollution, so they are national key management objects during the implementation of sustainable development; (2) Food processing enterprises. On account of food safety concerning the life safety of people, the health, sanitation, and environment-friendly package of products have always been extensively concerned by our society; and, (3) Electronics/electrical 
and automobile enterprises. Owing to more prominent global manufacturing and greater constraint by international environmental legal system, more attention shall be paid to energy conservation, emission reduction, and environmental protection.

Except the basic information about respondents in the questionnaire, the Likert 5 point scale is used for all variables to describe every problem. There are four questions about institutional pressure and the answers are divided into five grades, namely, $1=$ not important at all, 2 = unimportant, 3 = uncertain, $4=$ important, and $5=$ completely important. SSCP include four aspects: sustainable supply chain procurement, sustainable supply chain distribution, sustainable supply chain design, and investment recovery, and there are 15 questions in all. The answers are divided into five grades: $1=$ not considered, $2=$ prepare for consideration, $3=$ under consideration, $4=$ conduct a portion of practices, and $5=$ carry out practices completely. Environmental, social, and economic performances are included in enterprise performance. There are 12 questions totally, and their answers are graded, as follows: 1 = unavailable completely, 2 = available a little, $3=$ a certain extent, $4=$ more remarkable and $5=$ most remarkable. In the investigation, the respondents select proper scales according to the actual conditions of enterprises.

\subsection{Distribution and Collection of Questionnaires}

The questionnaires were distributed and collected from 12 March to 3 May 2017. In the investigation, 200 copies of questionnaires were released, of which 173 questionnaires were taken back. There were 156 valid copies of questionnaires, and the effective recovery rate was $78 \%$. The questionnaires are mainly distributed in the following two ways.

(1) Enterprise managers of university-enterprise cooperation enterprise make an investigation and distribute the paper questionnaires.

(2) Contact with enterprises through introduction by teachers, colleagues, students, and relatives, and distribute the questionnaires on the Internet.

After statistics summary of survey data, for the respondents' position, top managers, middle managers, and first-line managers account for $13.5 \%, 41.7 \%$, and $44.9 \%$, respectively (see Table 4 ). For enterprise type, the thermoelectric, chemical/petrochemical, food processing, electronic/electrical, automobile, and parts, other account for $12.2 \%, 14.1 \%, 26.9 \%, 21.8 \%, 13.5 \%$, and $11.5 \%$, respectively (see Table 5). For the term of enterprises taking part in sustainable supply chains for less than two years, 2 5 years, and at least five years account for $41 \%, 37.8 \%$, and $21.2 \%$, respectively (see Table 6).

Table 4. Statistical analysis on the respondents' position.

\begin{tabular}{cccc}
\hline Position & Frequency & Percent & Cumulative Percentage \\
\hline Top managers & 21 & $13.5 \%$ & $13.5 \%$ \\
Middle managers & 65 & $41.7 \%$ & $55.2 \%$ \\
First-line managers & 70 & $44.9 \%$ & $100.0 \%$ \\
\hline Total & 156 & $100.0 \%$ & \\
\hline
\end{tabular}

Table 5. Statistical analysis on enterprise type.

\begin{tabular}{cccc}
\hline Enterprise Type & Frequency & Percent & Cumulative Percentage \\
\hline Thermoelectric & 19 & $12.2 \%$ & $12.2 \%$ \\
Chemical/petrochemical & 22 & $14.1 \%$ & $26.3 \%$ \\
Food processing & 42 & $26.9 \%$ & $53.2 \%$ \\
Electronic/electrical & 34 & $21.8 \%$ & $75.0 \%$ \\
Automobile and parts & 21 & $13.5 \%$ & $88.5 \%$ \\
Others & 18 & $11.5 \%$ & $100.0 \%$ \\
\hline Total & 156 & $100.0 \%$ & \\
\hline
\end{tabular}


Table 6. Statistical analysis on the term of enterprises taking part in sustainable supply chains.

\begin{tabular}{cccc}
\hline Term & Frequency & Percent & Cumulative Percentage \\
\hline Less than 2 years & 64 & $41.0 \%$ & $41.0 \%$ \\
2 5 years & 59 & $37.8 \%$ & $78.8 \%$ \\
At least 5 years & 33 & $21.2 \%$ & $100.0 \%$ \\
\hline Total & 156 & $100.0 \%$ & \\
\hline
\end{tabular}

\subsection{Reliability and Validity Analysis}

\subsubsection{Reliability Analysis}

Reliability analysis is made on data by utilizing reliability analysis in SPSS 22.0, and the result is as shown in Table 7.

Table 7. Cronbach'aCoefficients of Institutional Pressure, SSCP, and Performance Outcome.

\begin{tabular}{ccccccccc}
\hline \multirow{2}{*}{ Cronbach' a Coefficients } & $\begin{array}{c}\text { Institutional } \\
\text { Pressure }\end{array}$ & & \multicolumn{2}{c}{ SSCP } & & \multicolumn{2}{c}{ Performance Outcome } \\
\cline { 2 - 9 } & CP & SP & SD & SDESI & IR & EVN & ECP & SOC \\
\hline a coefficient of subscale & 0.789 & 0.862 & 0.747 & 0.794 & 0.863 & 0.773 & 0.886 & 0.782 \\
a coefficient of total scale & 0.789 & \multicolumn{4}{c}{0.882} & & & 0.915 \\
\hline
\end{tabular}

It can be seen from Table 6 that Cronbach'a coefficient of total scale of institutional pressure is 0.789 , larger than 0.7 , indicating that the scale of institutional pressure is more reliable. The Cronbach's coefficients of subscale of SSCP are, respectively, 0.862, 0.747, 0.794, and 0.863, all of which are larger than 0.7. The Cronbach'a coefficient of total scale of SSCP is 0.882 , showing that the scale of SSCP has a higher reliability. In addition, Cronbach'a coefficients of environmental, economic, and social performances are, respectively, $0.773,0.886$, and 0.782 , all of which are larger than 0.7. The Cronbach'a coefficient of total scale of enterprise performance is 0.915 . A series of data prove that enterprise performance has a high reliability. Therefore, the questionnaires are reliable.

\subsubsection{Validity Analysis}

Validity analysis is made from content and construction validity. In the aspect of content validity, the questionnaires are designed by reference to a lot of references, and all the measurement questions are from the relevant references. Additionally, corresponding amendments and additions are made according to the needs of actual research. For instance, on the basis of TBL principle of sustainable supply chains, the measurement questions of social performance are added. The measurement questions of scales completely cover measurement contents, so the questionnaires meet the testing standards for content validity. The average variance extraction (AVE) is obtained by utilizing AMOS 22.0, and the analysis result is as shown in Table 8. The general discrimination standard is that the AVE is larger than 0.5 [47]. The calculation results show that the AVE values of institutional pressure, investment recovery, sustainable supply chain procurement, distribution, and design are larger than 0.5 , indicating that this scale has quite high construction validity. 
Table 8. Validity Test of Institutional Pressure, SSCP, and Performance Outcome.

\begin{tabular}{|c|c|c|c|}
\hline Grade I Index & Grade II Index & Factor Load & AVE \\
\hline \multirow{4}{*}{ Institutional pressure } & CP1 & 0.59 & \multirow{4}{*}{0.612} \\
\hline & $\mathrm{CP} 2$ & 0.66 & \\
\hline & $\mathrm{CP} 3$ & 0.71 & \\
\hline & $\mathrm{CP} 4$ & 0.75 & \\
\hline \multirow{5}{*}{ Sustainable supply chain procurement } & SP1 & 0.65 & \multirow{5}{*}{0.714} \\
\hline & SP2 & 0.86 & \\
\hline & SP3 & 0.75 & \\
\hline & SP4 & 0.78 & \\
\hline & SP5 & 0.63 & \\
\hline \multirow{4}{*}{ Sustainable supply chain distribution } & SD1 & 0.66 & \multirow{4}{*}{0.604} \\
\hline & SD2 & 0.72 & \\
\hline & SD3 & 0.61 & \\
\hline & SD4 & 0.62 & \\
\hline \multirow{3}{*}{ Sustainable supply chain design } & SDESI1 & 0.78 & \multirow{3}{*}{0.704} \\
\hline & SDESI2 & 0.83 & \\
\hline & SDESI3 & 0.65 & \\
\hline \multirow{3}{*}{ Investment recovery } & IR1 & 0.75 & \multirow{3}{*}{0.785} \\
\hline & IR2 & 0.90 & \\
\hline & IR3 & 0.82 & \\
\hline \multirow{4}{*}{ Environmental performance } & ENV1 & 0.67 & \multirow{4}{*}{0.543} \\
\hline & ENV2 & 0.74 & \\
\hline & ENV3 & 0.57 & \\
\hline & ENV4 & 0.50 & \\
\hline \multirow{5}{*}{ Economic performance } & EPC1 & 0.74 & \multirow{5}{*}{0.667} \\
\hline & EPC2 & 0.84 & \\
\hline & ЕРC3 & 0.76 & \\
\hline & EPC4 & 0.74 & \\
\hline & EPC5 & 0.56 & \\
\hline \multirow{3}{*}{ Social performance } & SOC1 & 0.79 & \multirow{3}{*}{0.708} \\
\hline & SOC2 & 0.85 & \\
\hline & SOC3 & 0.51 & \\
\hline
\end{tabular}

\section{Research on the Relationship between Institutional Pressure and Performance Outcome of Sustainable Supply Chain}

\subsection{Fitting Analysis on Structural Equation Model}

The structural equation modeling (SEM) is essentially a higher multivariate statistical method (e.g., measurement theory, factor analysis, regression, path analysis, and simultaneous equation modeling) to quantitatively describe the multiple relationships among various latent variables [48].

The SEM realizes the integration of factor analysis and regression analysis, which is the product of the combination of the two models, and it makes up for the shortcoming that the traditional factor analysis can't deal with the relationship between multiple variables at the same time. We know that the traditional statistical model, dealing with a single problem, even if it seems to be able to handle the relationship between several variables, the essence is to calculate the relationship between the two dependent variables, and still exclude the influence of other variables $[49,50]$. SEM seemed to be an appropriate tool in the present study, since our hypothetical model involves multiple-path linkages and was performed using the software package AMOS [51]. So, SEM is a very appropriate research methods for our research developed on the basis of previous studies [13,27,38]. 


\subsubsection{Fitting of Original Structural Equation Model}

(1) Original model of institutional pressure and SSCP

The actual institutional pressure, the investigation data of SSCP scale, and the previous theoretical structural model shall be combined organically, and the results are obtained, as shown in Figure 2, Tables 9 and 10 after analysis is made by using AMOS. The goodness-of-fit index is used to measure the matching degree between the assumed path analysis model and the actual investigation data. As for GFI, AGFI, NFI, and CFI adaptation standards, the following description is hereby given: the general discrimination criterion is greater than 0.9. However, due to more measurement indexes and complex model, the evaluation criterion is expanded to 0.8 .

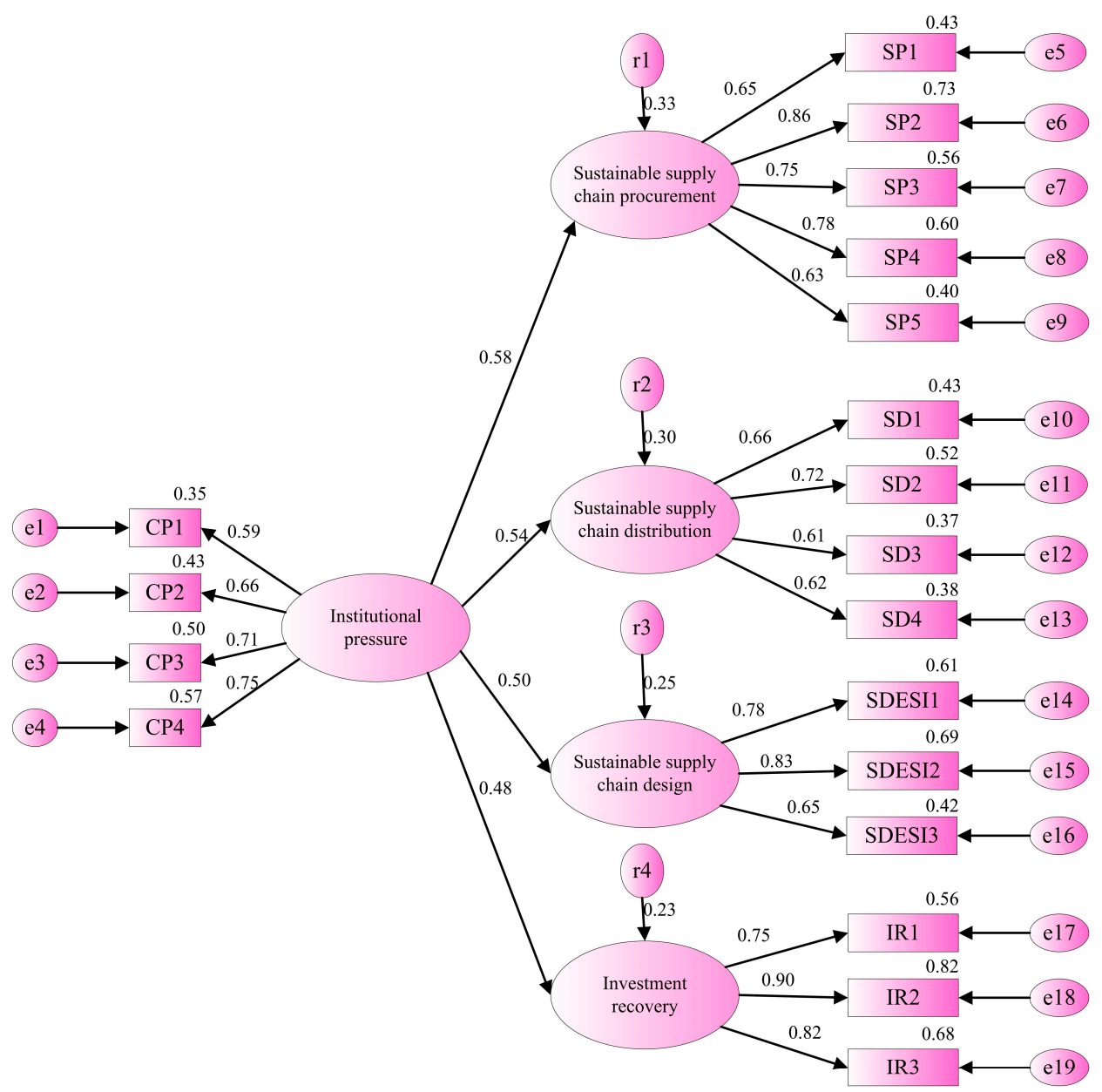

Figure 2. Path Analysis of Original Model of Institutional Pressure and SSCP.

It is analyzed from the angle of the basic fitting standard value that the minimum value of the factor load coefficient in the calculation result is 0.59 and the maximum value is 0.90 , which conform to the basic standard of 0.5 ; it is seen from the goodness of fit of the full model that the fitting index is 0.8 , showing that the model is well fit; as seen from the perspective of the modified index, the correction index is less than 4 , so the correction result is not significant. Therefore, it is unnecessary to consider increasing path; as seen from the perspective of path coefficient, Tables 5-12 shows that the path coefficients of institutional pressure against sustainable supply chain procurement, sustainable supply chain distribution, sustainable supply chain design, and investment recovery are positive, and $t$ values are, respectively, 5.298, 4.735, 4.800, and 4.813, all of which are greater than 1.96 . Hence, there is a significantly positive impact. To sum up, it is unneeded to modify the original model of institutional pressure and SSCP. 
Table 9. Causal Path Coefficient and Test of Original Model of Institutional Pressure and SSCP.

\begin{tabular}{llcccc}
\hline & Path & $\begin{array}{c}\text { Standardized } \\
\text { Path } \\
\text { Coefficient }\end{array}$ & $p$-Value & $t$-Value & $\begin{array}{c}\text { Whether } \\
\text { SIGNIFICANT } \\
\text { OR NOT } \\
(t>1.96)\end{array}$ \\
\hline $\begin{array}{l}\text { Sustainable supply } \\
\text { chain procurement }\end{array}$ & $<-$ institutional pressure & 0.58 & $* * *$ & 5.298 & Yes \\
\hline $\begin{array}{l}\text { Sustainable supply } \\
\text { chain distribution }\end{array}$ & $<-$ institutional pressure & 0.54 & $* * *$ & 4.735 & Yes \\
\hline $\begin{array}{l}\text { Sustainable supply } \\
\text { chain design }\end{array}$ & $<-$ institutional pressure & 0.50 & $* * *$ & 4.800 & Yes \\
\hline Investment recovery & $<-$ institutional pressure & 0.48 & $* * *$ & 4.813 & Yes \\
\hline \multicolumn{2}{c}{ Note: ${ }^{* *}$ Significant at $1 \%$ level. } & &
\end{tabular}

Table 10. Goodness of Fit of Original Model of Institutional Pressure and SSCP.

\begin{tabular}{cccccccc}
\hline Goodness-of-Fit Index & CMIN/DF & GFI & AGFI & NFI & CFI & RMSEA & PGFI \\
\hline Standard value & $<3$ & $>0.8$ & $>0.8$ & $>0.8$ & $>0.8$ & $<0.08$ & $>0.5$ \\
\hline Statistical value & 2.873 & 0.881 & 0.819 & 0.824 & 0.897 & 0.071 & 0.608 \\
\hline Whether the standards are met or not & Yes & Yes & Yes & Yes & Yes & Yes & Yes \\
\hline
\end{tabular}

Table 11. Causal Path Coefficient and Test of Original Model of SSCP and Enterprise Performance.

\begin{tabular}{|c|c|c|c|c|c|c|}
\hline & Path & & $\begin{array}{c}\text { Path } \\
\text { Coefficient }\end{array}$ & $p$-Value & $t$-Value & $\begin{array}{c}\text { Whether } \\
\text { Significant or Not } \\
(t>1.96)\end{array}$ \\
\hline $\begin{array}{l}\text { Environmental } \\
\text { performance }\end{array}$ & $<-$ & $\begin{array}{l}\text { Sustainable supply } \\
\text { chain procurement }\end{array}$ & 0.13 & 0.044 & 1.973 & Yes \\
\hline Social performance & $<-$ & $\begin{array}{l}\text { Sustainable supply } \\
\text { chain procurement }\end{array}$ & 0.01 & 0.866 & 0.169 & No \\
\hline $\begin{array}{l}\text { Environmental } \\
\text { performance }\end{array}$ & $<-$ & $\begin{array}{l}\text { sustainable supply } \\
\text { chain distribution }\end{array}$ & 0.16 & 0.041 & 1.981 & Yes \\
\hline Social performance & $<-$ & $\begin{array}{l}\text { sustainable supply } \\
\text { chain distribution }\end{array}$ & 0.42 & $* * *$ & 4.094 & Yes \\
\hline $\begin{array}{l}\text { Environmental } \\
\text { performance }\end{array}$ & $<-$ & $\begin{array}{l}\text { sustainable supply } \\
\text { chain design }\end{array}$ & 0.23 & 0.012 & 2.506 & Yes \\
\hline Social performance & $<-$ & $\begin{array}{l}\text { sustainable supply } \\
\text { chain design }\end{array}$ & 0.20 & 0.018 & 2.365 & Yes \\
\hline $\begin{array}{l}\text { Environmental } \\
\text { performance }\end{array}$ & $<-$ & investment recovery & 0.54 & $* * *$ & 5.233 & Yes \\
\hline Social performance & $<-$ & investment recovery & 0.42 & $* * *$ & 4.771 & Yes \\
\hline $\begin{array}{l}\text { Economic } \\
\text { performance }\end{array}$ & $<-$ & $\begin{array}{l}\text { environmental } \\
\text { performance }\end{array}$ & 0.19 & 0.021 & 2.019 & Yes \\
\hline $\begin{array}{l}\text { Economic } \\
\text { performance }\end{array}$ & $<-$ & social performance & 0.51 & $* * *$ & 4.934 & Yes \\
\hline $\begin{array}{l}\text { Economic } \\
\text { performance }\end{array}$ & $<-$ & $\begin{array}{l}\text { Sustainable supply } \\
\text { chain procurement }\end{array}$ & 0.12 & 0.045 & 1.963 & Yes \\
\hline $\begin{array}{l}\text { Economic } \\
\text { performance }\end{array}$ & $<-$ & $\begin{array}{l}\text { sustainable supply } \\
\text { chain distribution }\end{array}$ & 0.11 & 0.188 & 1.316 & No \\
\hline $\begin{array}{l}\text { Economic } \\
\text { performance }\end{array}$ & $<-$ & $\begin{array}{l}\text { sustainable supply } \\
\text { chain design }\end{array}$ & 0.16 & 0.029 & 2.178 & Yes \\
\hline $\begin{array}{l}\text { Economic } \\
\text { performance }\end{array}$ & $<-$ & investment recovery & 0.22 & 0.021 & 2.303 & Yes \\
\hline
\end{tabular}


Table 12. Goodness of Fit of Original Model of SSCP and Enterprise Performance.

\begin{tabular}{cccccccc}
\hline Goodness-of-Fit Index & CMIN/DF & GFI & AGFI & NFI & CFI & RMSEA & PGFI \\
\hline Standard value & $<3$ & $>0.8$ & $>0.8$ & $>0.8$ & $>0.8$ & $<0.08$ & $>0.5$ \\
\hline Statistical value & 2.856 & 0.879 & 0.808 & 0.845 & 0.817 & 0.073 & 0.557 \\
\hline Whether the standards are met or not & Yes & Yes & Yes & Yes & Yes & Yes & Yes \\
\hline
\end{tabular}

(2) Original model of SSCP and enterprise performance

Analyses on SSCP and investigation date of enterprise performance scale are conducted by utilizing AMOS, and the results are as shown in Figure 3 and Tables 11 and 12.

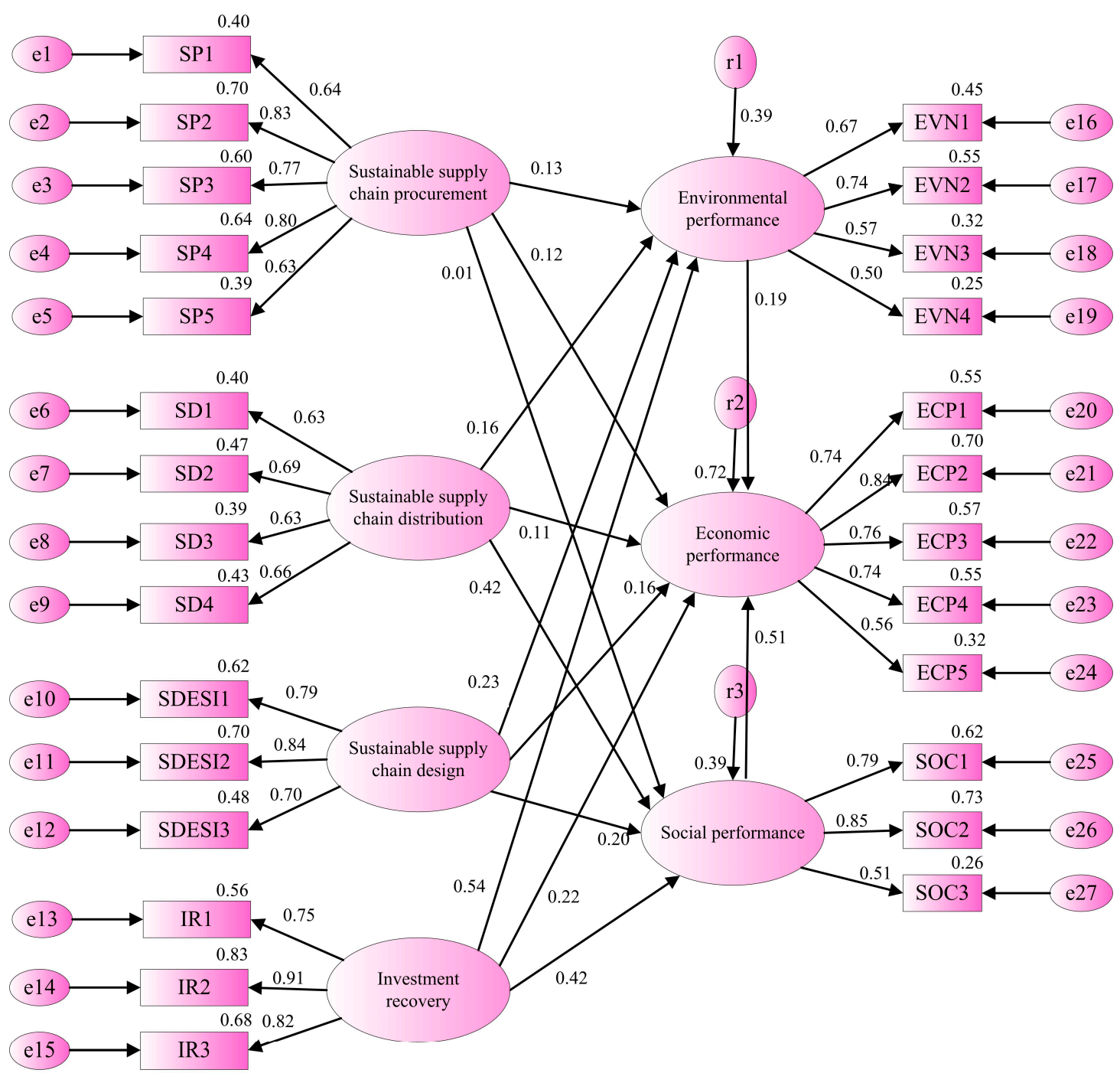

Figure 3. Analysis Path of Original Model of SSCP and Enterprise Performance.

It is analyzed from the angle of the basic fitting standard value that the minimum value of the factor load coefficient is 0.50 and the maximum value is 0.91 , which conform to the basic standard of 0.5; it is seen from the goodness of fit of the full model that the fitting index is 0.8 , showing that the model is well fit; it can be seen from Table 11 based on the perspective of path coefficient that the $t$ values of "sustainable supply chain procurement-social performance" and "sustainable supply chain distribution-economic performance" are, respectively, 0.169 and 1.316, less than 1.96 and not 
up to 0.05 of significance level. Therefore, it is necessary to modify the original model of SSCP and enterprise performance.

\subsubsection{Modification of Model}

(1) Modification of model for the first time

According to the analysis above, the $t$ values of "sustainable supply chain procurement-social performance", "sustainable supply chain distribution-economic performance" are less than 1.96. Therefore, the original model needs modifying. Modification shall first be considered from the realistic perspective to see if there are sufficient reasons to support the modification of the path, and then to modify the path one by one. When a path is modified, the model shall be retested.

The modification of the path "sustainable supply chain distribution-economic performance" is first considered herein. The original hypothesis is that sustainable supply chain distribution has a significantly positive impact on economic performance. In this investigation, what is mainly considered in the sustainable supply chain distribution is to reduce the use of energy during the distribution of products, use renewable energy sources in any transportation mode of products, upgrade freight logistics and transportation system, and track and monitor emission (carbon footprint) that is caused during the distribution. However, the use of renewable energy sources and the upgrading of transportation system will result in increased cost investment in the earlier stage, so economic performance is not significant. Therefore, it is theoretically supported to delete the path "sustainable supply chain distribution-economic performance". After deletion, the model shall be retested. The goodness of fit of modified model I for SSCP and enterprise performance first model modification is as shown in Table 13 (due to length limitation, path analysis diagram, causal path coefficient, and test table are omitted).

Table 13. Goodness of Fit of Modified Model I for SSCP and Enterprise Performance.

\begin{tabular}{cccccccc}
\hline Goodness-of-Fit Index & CMIN/DF & GFI & AGFI & NFI & CFI & RMSEA & PGFI \\
\hline Standard value & $<3$ & $>0.8$ & $>0.8$ & $>0.8$ & $>0.8$ & $<0.08$ & $>0.5$ \\
\hline Statistical value & 2.723 & 0.881 & 0.811 & 0.847 & 0.816 & 0.073 & 0.558 \\
\hline Whether the standards are met or not & Yes & Yes & Yes & Yes & Yes & Yes & Yes \\
\hline
\end{tabular}

It is analyzed from the perspective of the basic fitting standard value that the minimum value of the factor load coefficient is 0.5 and the maximum value is 0.91 , which conform to the basic standard of 0.5 ; it is seen from the goodness of fit of the full model that the fitting index is 0.8. Besides, when compared with the original model, the goodness of fit of the model is somewhat improved; as seen from the perspective of path coefficient, the $t$-value of the patch "sustainable supply chain procurement-social performance" is 0.089 , far less than 1.96 . Therefore, it is needed to modify the model for the second time.

(2) Modification of model for the second time

The path "sustainable supply chain procurement-social performance" is considered in the modification of the model for the second time. The original hypothesis is that sustainable supply chain procurement has a significantly positive impact on social performance. In this research, sustainable supply chain procurement only considers the ecological labels of products, environmental audit of internal management, ISO14001 certification, and environmental protection practice evaluation from the angle of suppliers instead of considering customers' wishes and salaries of employees in the purchasing department etc. from the viewpoint of client. Apart from that, it is found in the statistical analysis of samples that Chinese manufacturers account for $41.0 \%$ within two years in the implementation of SSCP and account for $78.8 \%$ within five years, indicating that SSCP of the manufacturing enterprises in our country are still in the initial stage. Therefore, the impact of 
sustainable supply chain procurement on social performance is not significant. It is theoretically supported to delete the path. After deletion, the model is modified and fit for the second time, and the results are shown in Figure 4 and Tables 14 and 15.

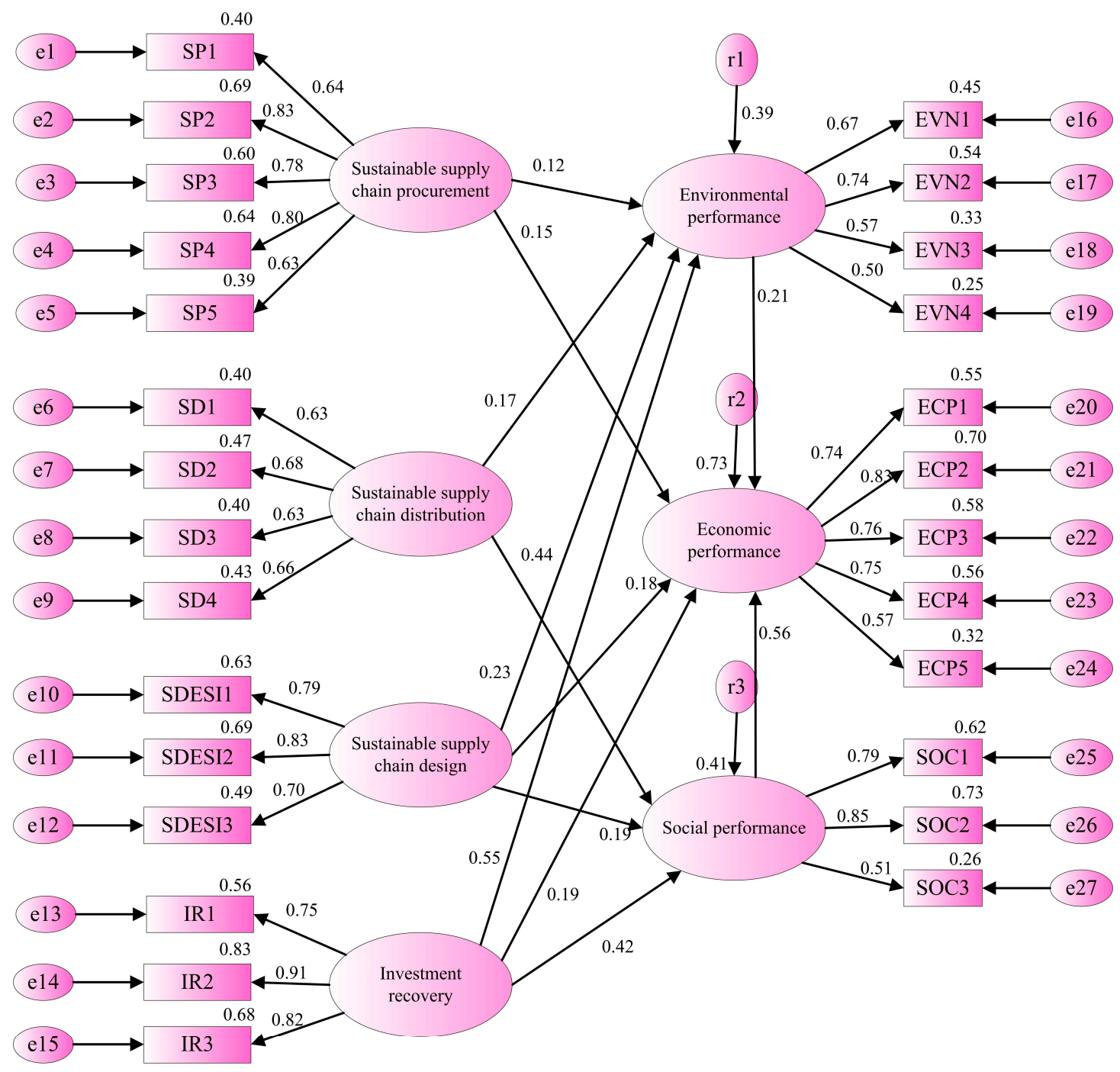

Figure 4. Analysis Path of Modified Model II for SSCP and Enterprise Performance.

It is analyzed from the angle of the basic fitting standard value that the minimum value of the factor load coefficient in the calculation result is 0.50 and the maximum value is 0.91 , which conform to 0.5 of basic standard; it is seen from the goodness of fit of the full model that the fitting index is 0.8 , showing that the model is well fit; as seen from the perspective of the path coefficient, the $t$ values of causal path coefficient of modified model II for SSCP and enterprise performance are greater than 1.96, reaching 0.05 of significance level. Therefore, it is feasible from the angle of the model to delete the path "sustainable supply chain procurement-social performance".

Comparison is made herein between the fitting index of the original model and its two modified models, and the result is as shown in Table 16. It is found through the comparison that the goodness of fit is obviously improved after modification. Therefore, it can be considered that the full model is up to the ideal standard. 
Table 14. Causal Path Coefficient and Test of Modified Model II for SSCP and Enterprise Performance.

\begin{tabular}{|c|c|c|c|c|c|c|}
\hline & Path & & $\begin{array}{c}\text { Path } \\
\text { Coefficient }\end{array}$ & $p$-Value & $t$-Value & $\begin{array}{c}\text { Whether } \\
\text { Significant or Not } \\
(t>1.96)\end{array}$ \\
\hline $\begin{array}{l}\text { Environmental } \\
\text { performance }\end{array}$ & $<-$ & $\begin{array}{l}\text { Sustainable supply } \\
\text { chain procurement }\end{array}$ & 0.12 & 0.048 & 1.971 & Yes \\
\hline $\begin{array}{l}\text { Environmental } \\
\text { performance }\end{array}$ & $<-$ & $\begin{array}{l}\text { sustainable supply } \\
\text { chain distribution }\end{array}$ & 0.17 & 0.018 & 2.62 & Yes \\
\hline Social performance & $<-$ & $\begin{array}{l}\text { sustainable supply } \\
\text { chain distribution }\end{array}$ & 0.44 & $* * *$ & 4.318 & Yes \\
\hline $\begin{array}{l}\text { Environmental } \\
\text { performance }\end{array}$ & $<-$ & $\begin{array}{l}\text { sustainable supply } \\
\text { chain design }\end{array}$ & 0.23 & 0.013 & 2.475 & Yes \\
\hline Social performance & $<-$ & $\begin{array}{l}\text { sustainable supply } \\
\text { chain design }\end{array}$ & 0.19 & 0.023 & 2.281 & Yes \\
\hline $\begin{array}{l}\text { Environmental } \\
\text { performance }\end{array}$ & $<-$ & investment recovery & 0.55 & $* * *$ & 5.224 & Yes \\
\hline Social performance & $<-$ & investment recovery & 0.42 & $* * *$ & 4.791 & Yes \\
\hline $\begin{array}{l}\text { Economic } \\
\text { performance }\end{array}$ & $<-$ & $\begin{array}{l}\text { environmental } \\
\text { performance }\end{array}$ & 0.21 & 0.032 & 2.149 & Yes \\
\hline $\begin{array}{l}\text { Economic } \\
\text { performance }\end{array}$ & $<-$ & social performance & 0.56 & $* * *$ & 6.108 & Yes \\
\hline $\begin{array}{c}\text { Economic } \\
\text { performance }\end{array}$ & $<-$ & $\begin{array}{l}\text { Sustainable supply } \\
\text { chain procurement }\end{array}$ & 0.15 & 0.021 & 2.308 & Yes \\
\hline $\begin{array}{c}\text { Economic } \\
\text { performance }\end{array}$ & $<-$ & $\begin{array}{l}\text { sustainable supply } \\
\text { chain design }\end{array}$ & 0.18 & 0.013 & 2.471 & Yes \\
\hline $\begin{array}{c}\text { Economic } \\
\text { performance }\end{array}$ & $<-$ & investment recovery & 0.19 & 0.027 & 2.215 & Yes \\
\hline
\end{tabular}

Note: ${ }^{* * *}$ Significant at $1 \%$ level.

Table 15. Goodness of Fit of Modified Model I for SSCP and Enterprise Performance.

\begin{tabular}{cccccccc}
\hline Goodness-of-Fit Index & CMIN/DF & GFI & AGFI & NFI & CFI & RMSEA & PGFI \\
\hline Standard value & $<3$ & $>0.8$ & $>0.8$ & $>0.8$ & $>0.8$ & $<0.08$ & $>0.5$ \\
\hline Statistical value & 2.593 & 0.894 & 0.847 & 0.850 & 0.829 & 0.064 & 0.560 \\
\hline Whether the standards are met or not & Yes & Yes & Yes & Yes & Yes & Yes & Yes \\
\hline
\end{tabular}

Table 16. Summary of Goodness of Fit of Original Model, Modified Model I and Modified Model II.

\begin{tabular}{cccccccc}
\hline Goodness-of-Fit Index & CMIN/DF & GFI & AGFI & NFI & CFI & RMSEA & PGFI \\
\hline Standard value & $<3$ & $>0.8$ & $>0.8$ & $>0.8$ & $>0.8$ & $<0.08$ & $>0.5$ \\
\hline Statistical value of original model & 2.856 & 0.879 & 0.808 & 0.845 & 0.817 & 0.073 & 0.557 \\
\hline Statistical value of modified model I & 2.723 & 0.881 & 0.810 & 0.847 & 0.816 & 0.071 & 0.558 \\
\hline Statistical value of modified model II & 2.593 & 0.894 & 0.847 & 0.850 & 0.829 & 0.064 & 0.560 \\
\hline
\end{tabular}

\subsection{Hypothesis Testing}

Hypothesis testing is made according to the ideal result of the full model and the verification result is as shown in Table 17. 
Table 17. Hypothesis Testing Result.

\begin{tabular}{|c|c|}
\hline Hypothesis & Testing Status \\
\hline $\begin{array}{l}\text { H1a. Institutional pressure has a significantly positive influence on sustainable supply } \\
\text { chain procurement. }\end{array}$ & Support \\
\hline $\begin{array}{l}\text { H1b. Institutional pressure has a significantly positive influence on sustainable supply } \\
\text { chain distribution. }\end{array}$ & Support \\
\hline H1c. Institutional pressure has a significantly positive influence on sustainable supply. & Support \\
\hline H1d. Institutional pressure has a significantly positive influence on investment recovery. & Support \\
\hline $\begin{array}{l}\text { H2a. Sustainable supply chain procurement has a significantly positive influence on } \\
\text { environmental performance. }\end{array}$ & Support \\
\hline $\begin{array}{l}\text { H2b. Sustainable supply chain design has a significantly positive influence on } \\
\text { environmental performance. }\end{array}$ & Support \\
\hline $\begin{array}{l}\text { H2c. Sustainable supply chain distribution has a significantly positive influence on } \\
\text { environmental performance. }\end{array}$ & Support \\
\hline $\begin{array}{l}\text { H2d. Investment recovery has a significantly positive influence on environmental } \\
\text { performance. }\end{array}$ & Support \\
\hline $\begin{array}{l}\text { H3a. Sustainable supply chain procurement has a significantly positive influence on } \\
\text { economic performance. }\end{array}$ & Support \\
\hline $\begin{array}{l}\text { H3b. Sustainable supply chain design has a significantly positive influence on economic } \\
\text { performance. }\end{array}$ & Support \\
\hline $\begin{array}{l}\text { H3c. Sustainable supply chain distribution has a significantly positive influence on } \\
\text { economic performance. }\end{array}$ & Not support \\
\hline H3d. Investment recovery has a significantly positive influence on economic performance. & Support \\
\hline $\begin{array}{l}\text { H4a. Sustainable supply chain procurement has a significantly positive influence on social } \\
\text { performance. }\end{array}$ & Not support \\
\hline $\begin{array}{l}\text { H4b. Sustainable supply chain design has a significantly positive influence on social } \\
\text { performance. }\end{array}$ & Support \\
\hline $\begin{array}{l}\text { H4c. Sustainable supply chain distribution has a significantly positive influence on social } \\
\text { performance. }\end{array}$ & Support \\
\hline H4d. Investment recovery has a significantly positive influence on social performance. & Support \\
\hline $\begin{array}{l}\text { H5. Environmental performance has a significantly positive influence on economic } \\
\text { performance. }\end{array}$ & Support \\
\hline H6. Social performance has a significantly positive influence on economic perfor & Support \\
\hline
\end{tabular}

\subsection{Result Analysis of Model and Countermeasures}

\subsubsection{Institutional Pressure and SSCP}

It can be seen from the research results that institutional pressure has a significant influence on sustainable supply chain procurement, distribution, design, and investment recovery, indicating that institutional pressure can promote SSCP and it is an important external driving force of making SSCM. Under multiple institutional pressures, enterprises will make corresponding sustainable management according to the requirements on the relevant laws and regulations for the purpose of not violating the laws and of reducing environmental compensation fees and relevant accident fines etc. Therefore, governments shall improve the relevant laws on SSCM as far as possible while encouraging enterprises to implement sustainable supply chain.

\subsubsection{Sustainable Supply Chain Procurement and Enterprise Performance}

It can be seen from the research results that sustainable supply chain procurement significantly impacts environmental and economic performances, but it does not significantly affect social 
performance, which is attributed to sustainable supply chain procurement that requires the purchased products to have ecological labels as much as possible, and it requires suppliers to have ISO 14001 certification and to make assessment on their internal environment and environmental protection practices, thereby the corporate environment needs to be improved, the consumption of poisonous and harmful substances needs to be reduced and the possibility of environmental accidents and relevant fines needs to be decreased. Sustainable supply chain procurement considers the sustainability of the purchased products from the supplier, but the use of the products with ecological labels and the assessment on the internal environment of suppliers will inevitably increase the basic cost of products, consequently leading to increased complaints from customers and insignificant social performance. To solve the problem, governments shall strengthen the publicity of SSCM to enable customers to understand, consequently reducing complaints.

\subsubsection{Sustainable Supply Chain Distribution and Enterprise Performance}

It can be seen from the research results that sustainable supply chain distribution has an obviously positive impact on environmental and social performances, but it still does not significantly impact economic performance, which is due to sustainable supply chain distribution requiring to use renewable energy during the distribution of products, to track the emission of wastes and upgrade the transportation system, consequently reducing the discharge of exhaust gas, thus improving the environment and enhancing corporate reputation, environment and social performance. However, the use of clean energy, the upgrading of transportation system and the installation of testing system will increase investment in the earlier stage. $78.8 \%$ of manufacturing enterprises implementing SSCP for less than five years are still in the pay-off period, so the economic performance is not significant. Therefore, governments shall provide policy support while enterprises make sustainable supply chain distribution.

\subsubsection{Sustainable Supply Chain Design and Enterprise Performance}

It can be seen from the research result that sustainable supply chain design can significantly affect environmental, economic, and social performances, and such effect is positive, which is attributed to sustainable supply chain design that requires the designed products to reduce the consumption of energy and raw materials in their life cycle so as to recycle them, and is attributed to prohibit the use of harmful materials. Such design can reduce the usage rate of harmful materials, decrease environmental accidents, and enhance corporate reputation. Moreover, the reduction of sustainable supply chain design can save energy to a certain extent.

\subsubsection{Investment Recovery and Enterprise Performance}

It can be seen from the research results that investment recovery positively impacts environmental, economic, and social performances, which is due to investment recovery paying more attention to recycling (or selling) excessive inventory or materials, waste materials produced in the marketing process, used materials, and limited capital equipment. When enterprises recycle (or sell) the surplus materials and idle equipment in the process of investment recovery, they will bring themselves non-business incomes, reduce environmental pollution that is caused by stacked waste materials and the waste of resources, improve corporate environment, and enhance employee satisfaction and corporate reputation.

\subsubsection{Enterprise Performance}

It can be seen from the research results that social and environmental performances positively, prominently impact economic performance, which is due to reducing the emission of exhaust gas, waste water, and solid waste and the consumption of hazardous/toxic substances, and decreasing the frequency of environmental accidents, consequently reducing the cost of energy consumption, waste 
handling cost, pollutant emission expenses, and environmental accident fines, enhancing employee and customer satisfactions and promoting corporate reputation.

\section{Conclusions and Prospect}

\subsection{Research Conclusions}

A hypothesis on the relationships between institutional pressures and SSCP and between SSCP and performance outcome is put forward herein, and a theoretical model is built. Investigation is made for five large types of manufacturing enterprises with the questionnaire method, and 156 valid copies of questionnaires are collected in all. A fitting test is conducted for the structural model by utilizing AMOS 22.0, and the optimal model is obtained after repeated modifications to initial model by means of goodness of fit and causal path coefficient. Hypothesis testing is carried out according to the optimal model and the research conclusion is drawn. It is concluded based on the research that institutional pressure has a significantly positive influence on SSCP; SSCP positively affects environmental performance; except sustainable supply chain distribution, other practice contents have a significantly positive influence on economic performance; except sustainable supply chain procurement, other practice contents have a significantly positive influence on social performance.

The findings mainly include six points: (1) Institutional pressures have a significant positive impact on sustainable supply chain management practices; (2) Sustainable supply chain procurement has a significant positive impact on environmental and economic performance, but the impact on social performance is not significant; (3) Sustainable supply chain distribution has a significant positive impact on environmental and social performance. For economic performance, although there is a positive effect, the significance level is not obvious; (4) sustainable supply chain design has a significant positive impact on economic, social, and environmental performance; (5) the impact of the implementation of investment recovery on economic, social, and environmental performance is very significant; and, (6) environmental and social performance have a significant positive impact on economic performance.

\subsection{Research Prospect}

The relationship between institutional pressure and performance outcome of sustainable supply chain is researched herein based on the structural equation model. Due to limited time, there are certain limitations in this paper, hereby giving the following prospects:

(1) The relationship between SSCP and performance outcome of enterprises is researched herein under the institutional pressure. However, enterprises are still faced with the pressures of supply chain, market demands, and competitors, etc. in the real life, while they implement SSCP. Therefore, other pressures can be taken into consideration in the future research to study the relationship among the above three pressures.

(2) It is concluded herein that institutional pressure can promote the implementation of SSCP and such practices can, in turn, improve enterprise performance. However, it is also an important research direction whether the improvement of enterprise performance can reversely promote SSCP.

(3) SSCP of Chinese manufacturing enterprises are researched herein. Due to lack of comparisons with developed countries, it may make further research on SSCP in the developed and other developing countries in the future, thereby the influence of potential factors, such as the differences in market scale, economic development, and legal institutions, etc. may be eliminated on the conclusion. Therefore, in order to improve the universality of research, it will be another research direction to repeat the research and compare, analyze the differences of different countries.

(4) The research mainly focuses on the manufacturing industry rather than other industries, such as service industry etc. Therefore, future research may be carried out on other industries. 
(5) The research selected limited indicators of the social performance; therefore, future research should draw on various indicators according to the GRI framework for social sustainability performance to carry out in-depth study.

Author Contributions: Y.L. carried out all research plan design and writing, C.Z. carried out questionnaire survey and structural equation modeling, and participated in the draft writing; L.X. participated in model updating and discussions, L.S. was responsible for paper supervision.

Funding: This research received no external funding.

Acknowledgments: (1) The authors are grateful to the anonymous reviewer for their valuable comments. (2) This work is supported by the National Natural Science Foundation of China (Grant No. 41771566), the Humanities and Social Science Project Funding of the Education Ministry of China (Project number: 16YJC630081) and the technology innovative team on water resources safety and clean energy collaborative management of Henan province (Henan provincial science and technology department). (3) The authors thank Huimin LI for enlightening discussions.

Conflicts of Interest: The authors declare no conflict of interest.

\section{References}

1. Zailani, S.; Jeyaraman, K.; Vengadasan, G.; Premkumar, R. Sustainable supply chain management (SSCM) in Malaysia: A survey. Int. J. Prod. Econ. 2012, 140, 330-340. [CrossRef]

2. Xu, X.; Zend, H. Sustainable supply chain management and circular economy capability: Based on the perspective of institutional pressure. Syst. Eng. Theory Pract. 2017, 37, 1793-1802.

3. Varsei, M.; Soosay, C.; Fahimnia, B.; Sarkis, J. Framing sustainability performance of supply chains with multidimensional indicators. Supply Chain Manag. Int. J. 2014, 19, 242-257. [CrossRef]

4. Elkington, J. Partnerships from cannibals with forks: The Triple Bottom Line of 21st-century business. Environ. Qual. Manag. 1998, 8, 37-51. [CrossRef]

5. Marconi, M.; Marilungo, E.; Papetti, A.; Germani, M. Traceability as a means to investigate supply chain sustainability: The real case of a leather shoe supply chain. Int. J. Prod. Res. 2017, 55, 6638-6652. [CrossRef]

6. Koeksal, D.; Straehle, J.; Mueller, M. Social Sustainable Supply Chain Management in the Textile and Apparel Industry-A Literature Review. Sustainability 2017, 9, 100. [CrossRef]

7. Ahi, P.; Searcy, C. An analysis of metrics used to measure performance in green and sustainable supply chains. J. Clean. Prod. 2015, 86, 360-377. [CrossRef]

8. Qorri, A.; Mujkić, Z.; Kraslawski, A. A conceptual framework for measuring sustainability performance of supply chains. J. Clean. Prod. 2018, 189, 570-584. [CrossRef]

9. Hanim Mohamad Zailani, S.; Eltayeb, T.K.; Hsu, C.C.; Choon Tan, K. The impact of external institutional drivers and internal strategy on environmental performance. Int. J. Oper. Prod. Manag. 2012, 32, 721-745. [CrossRef]

10. Lozano, R; Carpenter, A.; Huisingh, D. A review of 'theories of the firm' and their contributions to Corporate Sustainability. J. Clean. Prod. 2014, 106, 430-442. [CrossRef]

11. Boström, M.; Jönsson, A.M.; Lockie, S.; Mol, A.P.; Observer, P. Sustainable and responsible supply chain governance: Challenges and opportunities. J. Clean. Prod. 2015, 107, 1-7. [CrossRef]

12. Zeng, H.; Chen, X.; Xiao, X.; Zhou, Z. Institutional pressures, sustainable supply chain management, and circular economy capability: Empirical evidence from Chinese eco-industrial park firms. J. Clean. Prod. 2017, 155, 54-65. [CrossRef]

13. Esfahbodi, A.; Zhang, Y.; Watson, G.; Zhang, T. Governance pressures and performance outcomes of sustainable supply chain management-An empirical analysis of UK manufacturing industry. J. Clean. Prod. 2016, 155, 146-163. [CrossRef]

14. Ahi, P.; Searcy, C. A comparative literature analysis of definitions for green and sustainable supply chain management. J. Clean. Prod. 2013, 52, 329-341. [CrossRef]

15. Seuring, S.; Muller, M. From a literature review to a conceptual framework for sustainable supply chain management. J. Clean. Prod. 2008, 16, 1699-1710. [CrossRef]

16. Beske, P.; Land, A.; Seuring, S. Sustainable supply chain management practices and dynamic capabilities in the food industry: A critical analysis of the literature. Int. J. Prod. Econ. 2014, 152, 131-143. [CrossRef] 
17. Jian, X.; Yu, T. An evaluation on sustainable supply chain risks based on social responsibility of enterprises by taking automobile industry as an example. J. Hunan Univ. 2015, 29, 71-78.

18. Yang, X.; Jiang, Y. Optimal model for sustainable supply chain based on TBL theory. Mod. Manag. 2016, 63, 62-64.

19. Dimitrios, B.; Naoum, T.; Dimitrios, V.; Eleftherios, I. Sustainable supply chain management in the digitalization era: The impact of automated guided vehicles. J. Clean. Prod. 2017, 142, 3970-3984.

20. Zhu, Q. Collaborative management and innovation of sustainable supply chain. Chin. J. Manag. 2017, 14, 775-780.

21. Morali, O.; Searcy, C. A review of sustainable supply chain management practices in Canada. J. Bus. Ethics 2013, 117, 635-658. [CrossRef]

22. Paulraj, A.; Chen, I.J.; Blome, C. Motives and performance outcomes of sustainable supply chain management practices: A multi-theoretical perspective. J. Bus. Ethics 2015, 25, 299-318. [CrossRef]

23. Li, X.; Ting, W.; Jun, D. The impact of sustainable supply chain management practices on firm performance: An empirical study from china. J. Appl. Stat. Manag. 2017, 36, 693-702.

24. Esfahbodi, A.; Zhang, Y.; Watson, G. Sustainable supply chain management in emerging economies: Trade-offs between environmental and cost performance. Int. J. Prod. Econ. 2016, 181, 350-366. [CrossRef]

25. Wang, J.; Yang, J. Evaluation model and algorithm of sustainable supply chain performances based on structural entropy weight method and improved TOPSIS method. Chin. Mark. 2013, 15, 15-20.

26. De Sousa Jabbour, A.B.L.; de Oliveira Frascareli, F.C.; Jabbour, C.J.C. Green Supply Chain Management and Firms' Performance: Understanding Potential Relationships and the Role of Green Sourcing and Some Other Green Practices. Resour. Conserv. Recycl. 2015, 104, 366-374. [CrossRef]

27. Dai, J.; Jia, Q.; Xie, L.; Wang, J. Research of Performance Evaluation on Sustainable Supply Chain Based on Structural Equation Modeling. Ecol. Econ. 2015, 31, 86-89.

28. Haghighi, S.M.; Torabi, S.A.; Ghasemi, R. An Integrated Approach for Performance Evaluation in Sustainable Supply Chain Networks (with a Case Study). J. Clean. Prod. 2016, 137, 579-597. [CrossRef]

29. Deepak, M.; Kannan, G.; Noorul, A. Exploring the Impact of Dynamic Capabilities on the Performance of Sustainable Supply Chain Firmsby Using Grey-Analytical Hierarchy Process. J. Clean. Prod. 2017, 147, 637-653.

30. Erhun, M.O. A Legal Framework of Sustainable Environmental Governance in Nigeria. Front. Legal Res. 2016, 3, 24-38.

31. Ojo, A.; Mellouli, S. Deploying governance networks for societal challenges. Gov. Inf. Q. 2016. [CrossRef]

32. Edwards, D.B., Jr.; Brehm, W.C. The emergence of Cambodian civil society within global educational governance: A morphogenetic approach to agency and structure. J. Educ. Policy 2015, 30, 275-293. [CrossRef]

33. Setchfield, B.; Abbott, J. Planning and developing the North Lakes master planned community: Governance and the public interest in the network society. Aust. Plan. 2015, 52, 1-12. [CrossRef]

34. Thynne, I.; Peters, B.G. Addressing the Present and the Future in Government and Governance: Three approaches to Organising Public Action. Public Admin. Dev. 2015, 35, 73-85. [CrossRef]

35. Kutay, A. Limits of Participatory Democracy in European Governance. Eur. Law J. 2015, 21, $803-818$. [CrossRef]

36. Sang, M.L.; Kim, S.T.; Choi, D. Green Supply Chain Management and Organizational Performance. Ind. Manag. Data Syst. 2012, 112, 1148-1180.

37. Taylor, A.; Taylor, M. Antecedents of Effective Performance Measurement System Implementation: An Empirical Study of UK Manufacturing Firms. Int. J. Prod. Res. 2013, 51, 5485-5498. [CrossRef]

38. Zhu, Q.; Sarkis, J.; Lai, K. Examining the Effect of Green Supply Chain Management Practices and Their Mediation on Performance Improvement. Int. J. Prod. Res. 2012, 50, 1377-1394. [CrossRef]

39. Tan, K.H. Managing the Indirect Effects of Environmental Regulation and Performance Measurement. Ind. Eng. Manag. Syst. 2014, 13, 148-153. [CrossRef]

40. Lonzano, R. Envisioning sustainability three-dimensionally. J. Clean. Prod. 2008, 16, 1838-1846. [CrossRef]

41. Norazlan, A.N.I.; Habidin, N.F.; Roslan, M.H.; Zaini, M.; Zainudin, M.Z. The development of sustainable supply chain management practices and sustainable performance in malaysian healthcare industry. Int. J. Ethics Eng. Manag. Educ. 2014, 1, 51-55.

42. Green, K.W. Environmental collaboration and Monitoring Enhance Organizational Performance. Ind. Manag. Data Syst. 2012, 112, 186-205. [CrossRef] 
43. Mania, V.; Gunasekaranb, A. Four forces of supply chain social sustainability adoption in emerging economies. Int. J. Prod. Econ. 2018, 199, 150-161. [CrossRef]

44. Chardine-Baumann, E.; Botta-Genoulaz, V. A framework for sustainable performance assessment of supply chain management practices. Comput. Ind. Eng. 2014, 76, 138-147. [CrossRef]

45. Reefke, H.; Sundaram, D. Key themes and research opportunities in sustain-able supply chain management eidentification and evaluation. Omega 2017, 66, 195-211. [CrossRef]

46. Laari, S.; Töyli, J.; Solakivi, T.; Ojala, L. Firm performance and customer-driven green supply chain management. J. Clean. Prod. 2016, 112, 1960-1970. [CrossRef]

47. Wu, M. Operation and Application of Structural Equation Model-AMOS; Publishing House of Chongqing University: Chongqing, China, 2010; pp. 37-52.

48. Zhang, Y.; Hou, D.; Xiong, G.; Duan, Y.; Cai, C.; Wang, X.; Li, J.; Tao, S.; Liu, W. Structural equation modeling of PAHs in ambient air, dust fall, soil, and cabbage in vegetable bases of Northern China. Environ. Pollut. 2018, 239, 13-20. [CrossRef] [PubMed]

49. Flygansvær, B.; Dahlstrom, R.; Nygaard, A. Exploring the pursuit of sustainability in reverse supply chains for electronics. J. Clean. Prod. 2018, 189, 472-484. [CrossRef]

50. Liu, M. The analysis of affecting impacts on environmental behavior Based on structural equation model. Dongbei Univ. Financ. Econ. 2017, 11, 19-20.

51. Hong, J.; Zhang, Y.; Dinga, M. Sustainable supply chain management practices, supply chain dynamic capabilities and enterprise performance. J. Clean. Prod. 2018, 172, 3508-3519. [CrossRef]

(C) 2018 by the authors. Licensee MDPI, Basel, Switzerland. This article is an open access article distributed under the terms and conditions of the Creative Commons Attribution (CC BY) license (http:/ / creativecommons.org/licenses/by/4.0/). 